\title{
Dynamic Capacity Modelling of Soil Environment Carrying Capacity, and Developing a Soil Quality Early Warning Framework for Development
}

\author{
Land in China \\ Xiaonuo Li ${ }^{\mathrm{a}}$, Andrew B. Cundy ${ }^{\mathrm{b}}$, Weiping Chen ${ }^{\mathrm{a}, \mathrm{c}^{*}}$, Rui Liu ${ }^{\mathrm{d}}$, Sidan $\mathrm{Lv}^{\mathrm{e}}$ \\ ${ }^{a}$ Laboratory of Soil Environmental Science and Technology, Research Center for Eco-Environmental \\ Sciences, Chinese Academy of Sciences, Beijing 100085, China \\ ${ }^{\mathrm{b}}$ School of Ocean and Earth Science, University of Southampton, Southampton, SO14 3ZH, U.K. \\ ${ }^{c}$ College of Resource and Environment, University of Chinese Academy of Sciences, Beijing 100085, \\ China \\ d Academy of Science and Technology Innovation Strategy, Henan Academy of Sciences, Zhengzhou \\ 450002, China \\ ${ }^{\mathrm{e}}$ Key Laboratory of Ecosystem Network Observation and Modeling, Institute of Geographic Sciences and \\ Natural Resources Research, Chinese Academy of Sciences, Beijing 100101, China
}

\begin{abstract}
The knowledge of soil environmental quality and its changing trends is important for safe and sustainable land utilization. However, comprehensive information on soil environment carrying capacity, involving environmental, economic and social pressures, is relatively rare. In this study, a modified dynamic capacity model is developed to estimate soil environment carrying capacity in terms of a combined consideration of soil environment capacity, cumulative input/output rate and risk characteristics. Based on the method proposed, this paper demonstrates the current pollution status and remaining soil capacity of the Beijing urban area, and establishes a conceptual "early warning” model for soil environmental quality,

\footnotetext{
* Corresponding author. Tel.: +86 10 62843981; Fax: +86 10 62918177; E-mail address: wpchen@rcees.ac.cn.

List of acronyms

SECC: Soil Environment Carrying Capacity; SEQS: Soil Environmental Quality Standard; NAC: Natural Attenuation Capacity; SOM: Soil Organic Matter; Clay: Clay Content; CEC: Cation Exchange Capacity; PAHs: Polycyclic Aromatic Hydrocarbons; EPX: Ecosystem-service Performance Index; GB 36600-2018: the Risk Control Standard for Soil Contamination of Development Land.
} 
to predict time-dependent changing patterns of soil pollutants under different accumulation scenarios. The results showed that for Beijing soil environmental carrying capacity varied with land use type and pollutant. Compared with $\mathrm{Cu}, \mathrm{Zn}$ and $\mathrm{Pb}, \mathrm{Cd}$ posed the greatest threat to soil environmental carrying capacity in both residential areas and green parks. Heavy metal carrying capacity in soils in built-up areas in Beijing was not overloaded currently, and will not deteriorate significantly over the short- to medium-term in a hypothetical "decreased input" scenario. The method proposed provides a simple, cost-effective, and quantitative tool for mapping soil quality level, and assessing the need for risk management measures, in China and elsewhere.

Key words: Environmental capacity; Risk management; Prediction and early warning; Soil pollution prevention and control 


\section{Introduction}

Urban soils are a significant component of the urban environment, on one hand, provide invaluable ecosystem services (e.g., habitat provision, element cycling and biological regulation), and contribute to sustainable development (Aldieri et al., 2019; Legaz et al., 2017; Morgado et al., 2018); on the other hand, form critical sinks and sources of pollution affecting urban agro-ecosystem stability by input-output of pollutants e.g., via atmospheric precipitation, direct spillage and water runoff (Brtnický et al., 2019; Gu et al., 2016). Due to the intensification of human activity in urban areas soil pollution has increased dramatically, and is ubiquitous globally (Chen et al., 2020). In order to effectively manage soil pollution and mitigate soil environmental risks, the evaluation framework of soil environment carrying capacity is in pressing requirement to understand soil pollution level and its remaining capacity, based on which early warnings system can be established to predict pollution changing trends in time before soil environmental quality deteriorated.

\subsection{Soil environment carrying capacity (SECC)}

The concept of carrying capacity has been widely discussed and used in many fields of ecosystem management, including water environmental carrying capacity, vulnerability assessment of atmospheric environments, and land/soil carrying capacity (Zhang et al., 2016). SECC can be regarded as a complex function which not only assesses contamination risks in view of food quality and eco-toxicological effects on organisms in soils, but which also considers the maintenance of soil structure and capacity to support human socioeconomic activities (Li 2016; Zeng 2014). In 2016, the State Council of China issued a Soil Pollution Prevention and Control Action Plan, which stated that universities, research institutions and enterprises should cooperate to carry out basic research on soil environment quality standards, soil carrying capacity and environmental loading capacity, based on which policy and management methods could be developed at a local and regional scale (the State Council, 2016). In response, the study of SECC, and especially interrelated theory studies on soil environment capacity, soil environment quality standards and soil contamination prediction, has become a topic of significant focus for Chinese soil scientists. Especially, the definition 
of SECC, its evaluation methods, study frameworks and indicators have been primarily assessed (Wang et al., 2019; Zhou et al., 2017). Even with such efforts, the evaluation of SECC is still fraught with uncertainties and ambiguities constrained, in part, by 1) lack of an overall consideration of attributes reflecting soil multi-functionality; 2) difficulties in comprehensively assessing the interrelationships between anthropogenic land management and soil quality dynamics; 3) model deficiencies in measuring both quantitative and qualitative indicators; and 4) defining an acceptable and operational concept of SECC.

\subsection{Soil environment capacity}

Soil environment capacity can be an index for SECC evaluation, which shares dissimilarities as well as commonalities with SECC. Three key aspects - soil environmental quality standard, soil attenuation capacity and the evaluation method used - are consistently believed to be the most critical for studies on both soil environment capacity and SECC (Fu et al., 2014; Ma et al., 2016).

First, Soil Environmental Quality Standard (SEQS) of chemicals determine the degree of soil pollution, hence an important decision-support tool to understand soil environmental quality and capacity (Chen et al., 2018; Turan et al., 2019). The geochemical background values of chemicals in different regions (where available) and the national SEQS are usually used as the common soil evaluation standards (Kong et al., 2018; Zeng et al., 2019; Zhang et al., 2019), while different terminology is used, such as soil screening levels in the USA, target values in the Netherlands, (former) soil guideline values in the UK, investigation levels in Australia, and trigger values/levels in Germany, as these all display multi-objective functions or a range of values based on scientific research on the mutual interactions between soil pollutant concentrations and ecological or human health effects (Zhou et al., 2011).

Second, the tolerable level of soil pollutants is spatio-temporally dynamic due to both natural and socioeconomic factors (Chen et al., 2015; Chen et al., 2018; Song and Pijanowski, 2014). The pollutant removal/mitigation processes naturally occurring within soil ecosystems constitute Natural Attenuation Capacity (NAC), cause changes in distribution and accumulation of contamination, and eventually affect the range of soil dynamic capacity. 
Previous studies have shown that soil NAC is sensitive to at least two factors: (a) the physico-chemical properties of the soil, e.g. soil organic carbon accessibility may affect pollutant stabilization or sorption processes (Gan et al., 2019), and (b) the physico-chemical properties of the pollutant itself (Martz et al., 2019; van Wijnen et al., 2012). In addition, natural environmental and human-induced changes in the soil, such as rainfall, land cover, topography, geology, land management and pollution control interventions, can also help explain the variance of NAC (Kheir et al., 2014; Razanamahandry et al., 2018).

Third, according to the categories of soil environment capacity, there are two parallel ways to estimate the safe soil capacity before irreversible damage occurs, through a static capacity model or through a dynamic capacity model. The static capacity model has the advantage of using readily available parameters and being relatively easy to apply. However, static capacity model can greatly underestimate the result based on the hypothesis that no external or internal behaviors can occur to change the fate of pollutants ( $\mathrm{Li} 2019$ ). The dynamic capacity model is essentially an improved static capacity model, which expresses the spatiotemporal variability of soil environment capacity by simulating a dynamic interaction between socioeconomic systems and natural systems at the macroscale. Moreover, it can be applied to predict the content trend (i.e. temporal pollutant loading trend) and distribution pattern of pollutants in soil.

\subsection{Early warning for soil environmental quality}

Soil quality determines ecosystem functions, and so information on the magnitude, location and direction of soil quality changes is critical for strategizing remedial measures before irreversible damage occurs (Obade 2019). Considerable efforts have been made to develop methods and models to predict the spatio-temporal dynamics of pollutants in soil, and propose early warning measures preventing pollutant accumulation that exceed soil quality standards, food security standards or health risk thresholds. The employed methods including logistic regression (Guan et al., 2019; Kumar et al., 2019; Zhang et al., 2019), risk/pollution index (Cachada et al., 2016; Chon et al., 2017; Malina and Mazlova, 2017); gray prediction models (Wang 2018), index frameworks (Gao et al., 2015), STEM-profile models (Zhao et al., 
2012), mass balance models (Peng et al., 2016; Shi 2019; Zhang et al., 2019), cumulative rate model (Zhao et al., 2019), and geostatistical interpolation (Fan et al., 2019; Sun et al., 2019). These methods perform very differently, but all can meet the demand to predict the temporal or spatial variation of pollutants in soil. However, these methods may be limited by data availability, are often time consuming and labor intensive, and are subject to individual preference and other factors.

In order to choose a simple and effective method to comprehensively evaluate SECC and predict soil environmental quality, in this study, the dominant factors that SECC is susceptible to are identified covering soil properties, land function, pollutants, risk characteristics and social-economic activity; consequently, a new dynamic model is provided to depict the interaction between relevant indicator sets and SECC. Based on SECC approach and health risk level, an early warning model for soil environmental quality for development land is further build to classify the quality level of the soil environment, and predict changing trends of pollutants in soil under different accumulation scenarios. Finally, the effectiveness of the proposed method, framework and model are verified by applying it to soils in the Beijing urban area, China.

\section{Methodology}

\subsection{Methodology for SECC}

\subsubsection{Indicator system}

Based on the concept of SECC, a comprehensive evaluation indicator system for SECC should cover multidimensions of land function, soil pollution, social economy and land spatial planning to reflect the impacts of human socio-economic activities on the soil environment. In principle, indicators should be sensitive to changes over time, refer to benchmark or threshold values, be predictive or anticipatory and convey relevance to the stated objectives of the assessment (Obade 2019). According to expert preferences and literature review, the selection of SECC evaluation indicators here was based on conformance to being 1) comprehensive and systematic; 2) representative and simple; 3) applicable to both static and dynamic situations/modelling; and 4) feasible and operable. In this sense, a conceptual framework for 
SECC is depicted in Fig. 1, in which NAC of soil provided the basis. Sixteen dominant factors affecting soil environmental load were selected and categorized into three indicator sets, referring to soil environment capacity, cumulative rate and risk characteristics.

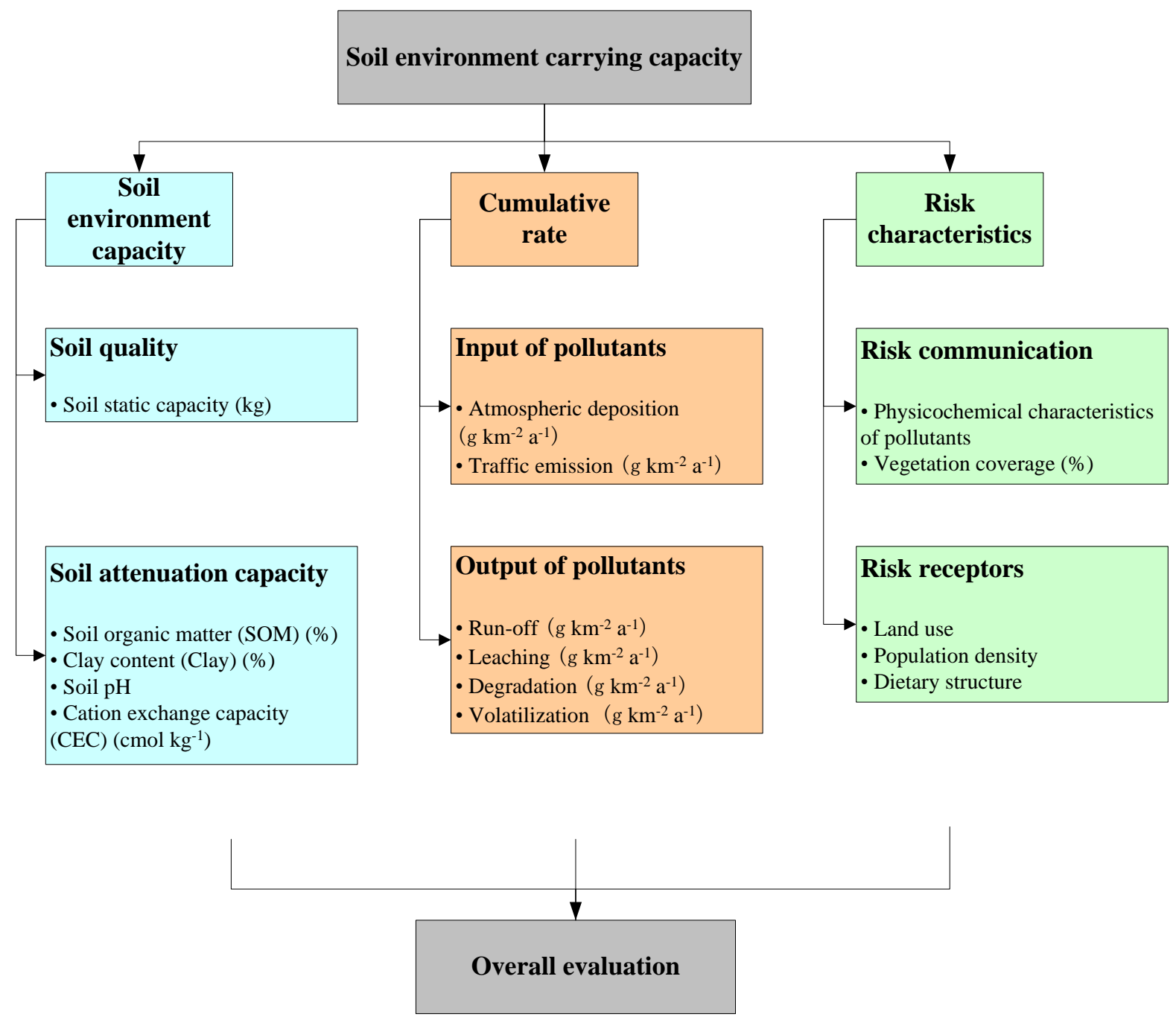

Fig. 1. Tree diagram of a comprehensive evaluation indicator system for SECC.

As shown in Fig. 1:

(1) Indicator set of soil environment capacity

Soil environment capacity is the key component for SECC evaluation, which is increasingly used to reflect the extreme or threshold value that can be reached while still maintaining the normal structure and function of the soil ecosystem. Basically, the higher the soil environment capacity, the higher the SECC. In this study, two sub-categories of (a) soil quality (as soil static capacity, defined as the remaining concentration when comparing the 
current concentrations of pollutants with the related SEQS) and (b) soil attenuation capacity are taken into consideration to measure the dynamic processes of input, output and accumulation of pollutants in soil over time, which means a wider boundary covers both the status of soil environmental quality and the soil's ability to "accommodate" pollutants. However, NAC varies greatly due to the nature of the pollutants, the soil heterogeneity, and the complexity of soil biogeochemical processes, and how to quantify soil NAC and with which indicators is still debated (Calzolari et al., 2016; Thomsen et al., 2012). Considering (a) the dominant role that soil physical and chemical properties play in the ecological process of pollutants (i.e. dissolution, sorption, sequestration and precipitation processes) in urban soil, and (b) ease of measurement, four summary parameters are included here as proxy indicators for NAC in urban soil, namely soil organic matter (SOM), clay content (Clay), soil pH and cation exchange capacity (CEC).

(2) Indicator set of cumulative rate

The action of soils as sinks or pathways for potential pollutants, and their response to human social and economic activities, are crucial elements when assessing the cumulative increase (or decrease) of pollutants in soil. Among possible sources of soil contamination caused by anthropogenic behaviors, atmospheric deposition and traffic emission are the dominant sources for urban soil pollution (Chai and Cui, 2019; Peng et al., 2012 and 2017), which therefore are used as input indicators in the cumulative rate indicator set (Figure 1). While soil-pollutant interaction processes incorporate a diversity and complexity of mechanisms, the route (from source to fate) of pollutants in soil can however be summarised by a few main processes (Durães et al., 2018; Wuana et al., 2014). In term of urban soil, four output indicators are preferred here, corresponding to (Csavina et al., 2012; Durães et al., 2018; Prokop et al., 2016): 1) runoff: a physical process whereby the transport of pollutants occur either by soil erosion or via surface water bodies; 2) leaching: the vertical migration of pollutants from subsoil to deeper layers or groundwater; 3) volatilization: the chemical release of a pollutant from a liquid or a solid matrix into a gaseous phase, or into the atmosphere; 4) 
degradation: a physical, chemical, biological or combined process which changes the available content of pollutants in soil.

(3) Indicator set of risk characteristics

Even with the same soil environment capacity and cumulative rate, SECC varies spatially due to differences in pollutant properties, the type of land use, contaminant pathways or linkages, risk receptors, and natural conditions in the investigated sites. From the perspective of risk function mechanism, risk indicators are identified as:

- Physicochemical characteristics of pollutants: Different pollutants show different toxicity characteristics and risk exposure pathways. For example, heavy metals can be classified as extremely poisonous, moderately poisonous and relatively less poisonous according to their level of toxicity on soil microorganisms (Ashraf et al., 2019; Mukherjee et al., 2019). At high concentration $\mathrm{Zn}$ causes toxicity in plants, while $\mathrm{Cd}$ rarely causes phytotoxicity (Ryzhenko et al., 2017). The concentration of ionic $\mathrm{Cu}$ in soil solution is typically very low but the form of hyperoxide radicals for example is carcinogenic when interacting with thiol compounds in cell membranes (Lockwood et al., 2015).

- Vegetation coverage: The vegetation coverage rate is on one hand closely relevant for the type of land use, on the other hand, impacts air deposition, retention and release processes based on air-soil or soil-water exchange (Li et al., 2018; Luo et al., 2019). Atmospheric pollutants are primarily scavenged and stored by vegetation, then transferred into soil through falling litter, or back into the air by re-volatilization (Bao et al., 2016; Terzaghi et al., 2017). By initially intercepting and retaining pollutants (e.g. on foliage and root), plants are often used as biological filters, to some extent, determine the level of contamination that can be expected in soil (Gonze and Sy, 2016; Luo et al., 2019).

- Land use: The SECC under different land use patterns can be further affected by the heterogeneity of risk expressions, which is fundamentally determined by toxicity of pollutants, exposure pathways and risk receptors. Firstly, the same pollutant in soils of different land uses can show a changing toxicity (Islam et al., 2017), because of the different soil physicochemical properties ( $\mathrm{SOM}, \mathrm{pH}$, etc.) and the diversity of the soil 
microbial community under various land use types and soil depths (Simon et al., 2013; Zhao et al., 2019). Secondly, as the significant exposure media in urban areas, soils of different land uses can deliver pollutants to receptors through different pathways, including ingestion, dermal contact or inhalation (Bright et al., 2006; de Miguel et al., 2007). Additionally, ecological elements and human beings exposed to pollutants vary significantly from residential use to commercial land, suggesting a considerable to very high degree of exposure risk.

- Population density: Pollutants in contaminated soil may have serious impacts on human health. Population density and growth are closely related to accumulation patterns of pollutants in soil, and in turn, higher potential health risk implies a higher population density of exposed inhabitants close to contaminated sites (Acosta et al., 2015; Li et al., 2019). Typically, children are more sensitive and easily exposed to high non-cancer risk than adults (Zeng et al., 2019).

- Dietary structure: Soil contamination has historically impacted food safety which poses an important threat to human health (Ramón and Lull, 2019). The public health risk will be more severe if there is dietary exposure to food and drinking water from contaminated land, especially the increasing problem of contamination of farmland and crops by heavy metals (Islam et al., 2017; Wei and Yang, 2010). Compared with a sole intake of food or drinking water from a contaminated site, a diversity of food (and water) supply will offset the health risk conveyed by the food chain, which allows a relative high SECC by protecting risk receptors.

\subsubsection{Evaluation method}

The calculated SECC value based on soil environment static capacity is theoretically the maximum pollutant load that can be borne by the soil before an unacceptable health risk occurs. In a more realistic manner, for the safe and sustainable utilization of urban land, safety coefficients should be set up to correct the upper limit of SECC to incorporate data uncertainties and safety margins, within the prevailing acceptable risk and risk management framework of an area. To capture the SECC safety margin, the attenuation coefficient, 
cumulative coefficient and risk coefficient are defined on the basis of three sub-categories and sixteen indicators proposed in Figure 1. The evaluation model for SECC is expressed in the following equation:

$$
\mathrm{SECC}=d \times \rho \times A \times\left(S_{\mathrm{i}-} C_{\mathrm{i}}\right) \times F_{1} \times F_{2} \times F_{3}
$$

Where: $d$ represents soil depth (in $\mathrm{m}-0.2$ meter of topsoil is usually applied); $\rho$ represents bulk density $\left(\mathrm{kg} \mathrm{m}^{-3}\right)$; A represents the area of the studied land or region $\left(\mathrm{km}^{2}\right) ; C_{\mathrm{i}}$ represents the concentration of pollutant i $\left(\mathrm{mg} \mathrm{kg}^{-1}\right) ; S_{\mathrm{i}}$ represents the evaluation standard of soil environmental quality for pollutant $\mathrm{i}\left(\mathrm{mg} \mathrm{kg}^{-1}\right) . F_{1}, F_{2}$, and $F_{3}$ are the attenuation coefficient, cumulative coefficient and risk coefficient, respectively. The value of safety coefficients are all between 0 and 1 .

(1) Attenuation coefficient $\left(F_{1}\right)$

This study applied NAC of soil to describe the soil attenuation coefficient, which has been widely calculated using the ecosystem-service performance index (EPX) (Rutgers et al., 2012; Wang et al., 2015; Xie et al., 2018). As discussed previously, in the context of urban soil and key pollutants, here we utilize four dominant parameters (SOM, Clay, $\mathrm{pH}$ and CEC) as core evaluation variables to quantify the performance of NAC. The modified equation is shown as:

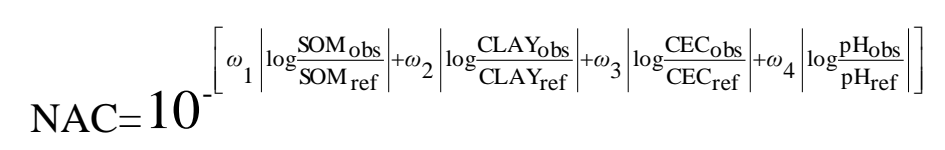

Where: Subscripts "obs" and "ref" denote the observed and reference values of corresponding parameters; and the entropy weight $\omega_{\mathrm{i}}(\mathrm{i}=1,2,3$, or 4$)$ denotes the contribution of the corresponding parameters to NAC, whereby a higher weight coefficient means greater significance. Note that the most important parameters affecting NAC and their contributions vary with changes in soil properties and pollutant features. Thus, the adjustment of parameters and weights is necessary and vital in specific studies.

(2) Cumulative coefficient $\left(F_{2}\right)$ 
The cumulative coefficient is determined by the ratio of the annual cumulative amount of pollutants in soil to the soil environment static capacity, and is estimated by the following equation:

$$
F_{2}=1-\frac{\Delta \mathrm{acc}}{d \times \rho \times A \times\left(S_{\mathrm{i}}-C_{\mathrm{i}}\right)}
$$

Where: $\Delta$ acc is the annual cumulative amount of pollutants in soil $\left(\mathrm{kg} \mathrm{a}^{-1}\right)$, controlled by the dynamic balance of input $\left(I_{\text {in }}\right)$ and output $\left(I_{\text {out }}\right)$ pathways. Here we assume atmospheric deposition $\left(I_{\mathrm{atm}}\right)$ and traffic emission $\left(I_{\text {traf }}\right)$ provide the main input flux for the increase of soil pollutants, meanwhile, pathways such as soil erosion and surface water runoff $\left(I_{\mathrm{run}}\right)$, leaching $\left(I_{\text {lea }}\right)$, volatilization $\left(I_{\mathrm{vol}}\right)$ and degradation $\left(I_{\mathrm{deg}}\right)$ take elements out of the soil ecosystem. The total flux is formulated as follows:

$$
\Delta \text { acc }=I_{\text {in }}-I_{\text {out }}=I_{\text {atm }}+I_{\text {traf }}-\left(I_{\text {run }}+I_{\text {lea }}+I_{\text {vol }}+I_{\text {deg }}\right)
$$

There are many studies that aim to predict the cumulative increments of pollutants in soil by establishing innovative models (Franco-Uria et al., 2009; Huang et al., 2018; Peng et al., 2017; Zhang et al., 2019). However, the dynamic processes related to the accumulation, and input and output, of specific pollutants are diverse and complicated. To simplify the calculation, the residual rate $(K)$ is usually assumed as the percentage of pollutants remaining in the soil ecosystem after a variety of input and output pathways, especially, in scenarios of heavy metal accumulation (Li et al., 2011). Thus, $\Delta$ acc can be expressed as the multiple of input intensity and residual rate $(K)$. The $K$ value can be experimentally determined, empirical, or defined from literature.

(3) Risk coefficient $\left(F_{3}\right)$

The risk coefficient is characterized as the reciprocal of the total potential risk of exposure to pollutants in the soil. The lower the risk coefficient, the smaller the SECC. The Analytic Hierarchy Process (AHP) approach can be effective in calculating risk coefficients because of its ability to integrate qualitative and quantitative information into a comprehensive evaluation ( $\mathrm{Li}$ et al., 2018). The total potential risk $(R)$ is the sum of the determinants of seven factors, but each factor has its own weight. $R$ is expressed in the following relationship: 


$$
R=\omega_{1} \times\left(\sum_{i=1}^{2}\left(\omega_{1 i} \times S_{1 i}\right)\right)+\omega_{2} \times\left(\sum_{j=1}^{3}\left(\omega_{2 j} \times S_{2 j}\right)\right)
$$

Where: $S_{\mathrm{ij}}(\mathrm{i}=1$ or $2 ; \mathrm{j}=1,2$, or 3 ) represents the determinant of each factor; $\omega$ represents the weight specified for each factor, generally through expert consultation.

\subsection{Methodology for early warning}

\subsubsection{Early warning system}

In terms of denotation of an early warning system for soil environmental quality, SECC is used here as the theoretical basis for evaluating soil environmental quality and predicting its time-dependent changing pattern. Influencing factors of soil pollution as well as input-output fluxes analysis play critical roles in simulating long term trends for pollutant accumulation in soil. A set of other attributes, e.g. regional policies, industrial planning, environmental protection measures and social awareness, help to construct possible future scenarios for soil pollution. However, soil function causes significant differences in soil quality and pollution accumulation, which indicates that the diverse elements constituting early warning models rely on land use type. For an overall consideration, soil environmental quality, the quality of agricultural products and the sustainable use of land resources should all be included to establish a management mechanism supporting an early warning system for agricultural land. In contrast, for development land human exposure is the domain risk receptor (Fig. 2). 


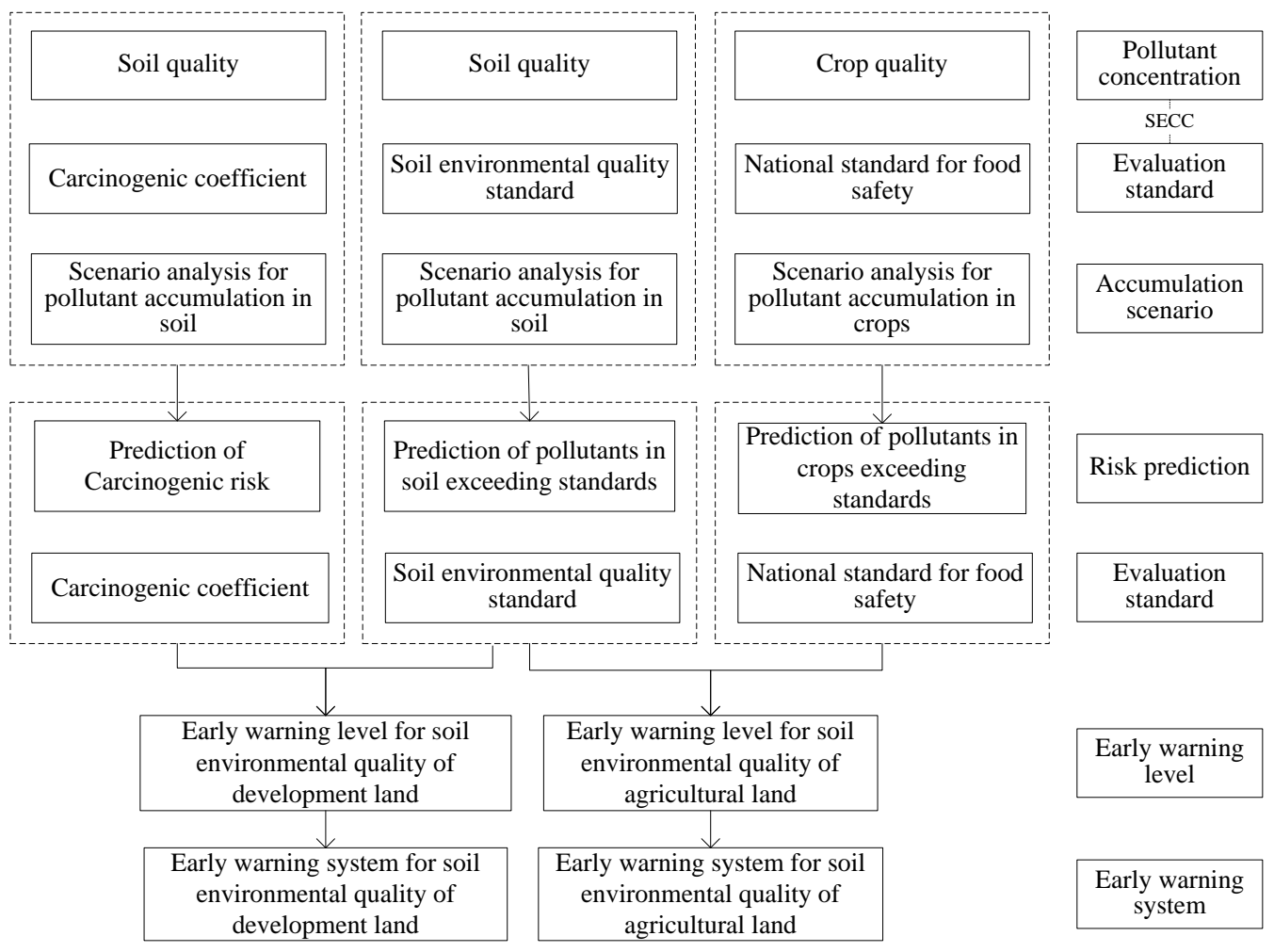

Fig. 2. Early warning system for soil environmental quality.

Given SECC as the upper limit of soil environmental quality at an acceptable level, for simplicity we assume that the cumulative rate under different scenarios remains steady. The time period of exceeding the specific standard $(Y)$ is predicted by a reduced equation:

$$
Y=\frac{\mathrm{SECC}}{\Delta \mathrm{acc}}
$$

Where: SECC and $\triangle$ acc are both defined in the above equations. According to the assumption of different soil pollution scenarios, $\Delta$ acc is modeled differently based on the environmental processes of soil pollution.

\subsubsection{Early warning level}

Regarding pollution levels for human health concern, a national standard for soil environmental quality was jointly launched by the Ministry of Ecology and Environment of the People's Republic of China and the State Administration for Market Regulation in 2018 Soil Environmental Quality Risk Control Standard for Soil Contamination of Development Land (for Trial Implementation) (GB 36600-2018). By comparing the current concentration of pollutants with screening levels or control levels defined in GB 36600-2018, the application 
of this standard is expected to declare whether the soil is polluted, whether the health risk is unacceptable and whether the land requires remediation actions. Corresponding to GB 36600-2018, three generic reference levels of screening level, carcinogenic level and control level are considered here as threshold values for soil environmental quality of development land to divide the early warning classification. As a result, five grades are grouped in Fig. 3, implying that a generally higher health risk is reflected in a higher early warning level. Specifically:

- The low level of early warning: comprising the $1^{\text {st }}$ level and the $2^{\text {nd }}$ level, where the pollutant concentration in soil is below the screening level. The difference between the $1^{\text {st }}$ level and the $2^{\text {nd }}$ level depends on the predicted time within which the pollution content reaches the screening level. The predicted timespan in the scenario of the $1^{\text {st }}$ level is more than 50 years, whereas in the scenario of the $2^{\text {nd }}$ level this is less than 50 years.

- The medium level of early warning: comprising the $3^{\text {rd }}$ level and the $4^{\text {th }}$ level, where the pollutant concentration in the soil surpasses the screening level but is below the control level. The difference between the $3^{\text {rd }}$ level and the $4^{\text {th }}$ level depends on the threshold value of carcinogenic risk. Generally, a carcinogenic risk of $10^{-6} \sim 10^{-4}$ is widely considered acceptable, whereas surpassing $10^{-4}$ or falling below $10^{-6}$ is respectively regarded as significant hazard or negligible risk (Li et al., 2014). According to the derivation method for risk management and control levels defined in GB 36600-2018, and conforming to the current environmental management requirements in China, we employ a carcinogenic risk of $10^{-5}$ to distinguish the $3^{\text {rd }}$ level and the $4^{\text {th }}$ level.

- The $5^{\text {th }}$ level is ranked as the highest level of early warning, whereby the pollutant concentration in soil surpasses the control level and may generate significant health effects, and remediation projects are mandatory to address the soil pollution issue. 


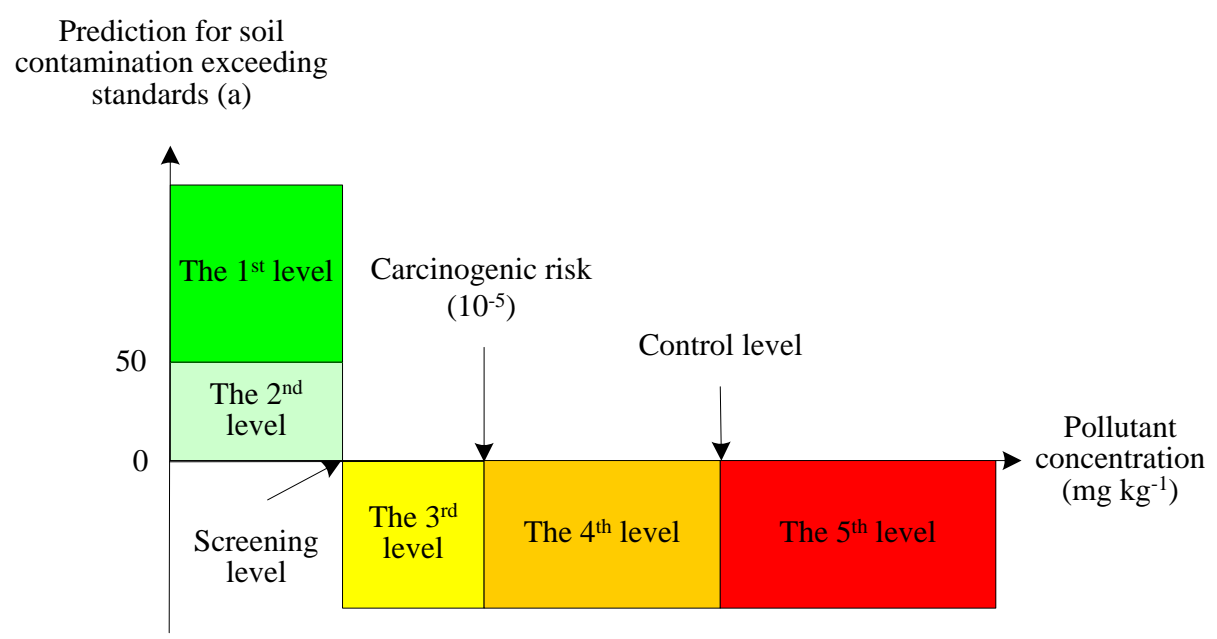

Fig. 3. The early warning level for soil environmental quality.

\section{Case study}

\subsection{Study area}

Beijing is the capital of China with a population of 21.73 million people (BJ Stats 2017). The built-up area of Beijing is divided by five concentric ring roads covering about $670 \mathrm{~km}^{2}$ in 2012. Heavy metals, especially $\mathrm{Pb}, \mathrm{Cd}, \mathrm{Cu}$ and $\mathrm{Zn}$, are widespread pollutants in the built-up area of Beijing, moreover, the overall pollution level is increasing gradually year by year (Cao et al., 2014; Wang et al., 2012a and 2012b). Based on the theoretical framework and methodology proposed previously, residential areas and green parks within the $5^{\text {th }}$ ring road were selected to verify the effectiveness of SECC model and early warning system: 1) evaluate the $\mathrm{SECC}$ for $\mathrm{Pb}, \mathrm{Cd}, \mathrm{Cu}$, and $\mathrm{Zn}$; and 2) predict their changing pollutant loading trends at different accumulative rates, and the "safe lifespan" regulated by SECC.

\subsection{Data collection}

Land uses were delineated from high-resolution remote sensing images of IKONOS (Liu et al., 2016), among which, the area of residential and green parks are respectively 536.65 $\mathrm{km}^{2}$ and $80.68 \mathrm{~km}^{2}$. In Table 1, according to the latest soil quality standard, the baseline concentration of $\mathrm{Pb}, \mathrm{Cd}$ and $\mathrm{Cu}$ refers to $\mathrm{GB} 36600-2018$, while, that of $\mathrm{Zn}$ refers to Screening Levels for Soil Environmental Risk Assessment of Sites (DB11T811-2011). The observed concentration of pollutants and soil property indicators (including $\mathrm{pH}$, Clay, SOM and CEC) are average values acquired from the experimental results published by Liu et al., 
2016 (Table 1, Table 2), in which the study area was divided into $1 \mathrm{~km} \times 1 \mathrm{~km}$ sized grids on Google Earth, and then sample sites were selected from each grid based on the land use and topographic conditions (some grids were unavailable for sampling). Finally, 106 sample sites were selected (Fig. 4) and surface soil (0-20 cm depth) samples were collected.

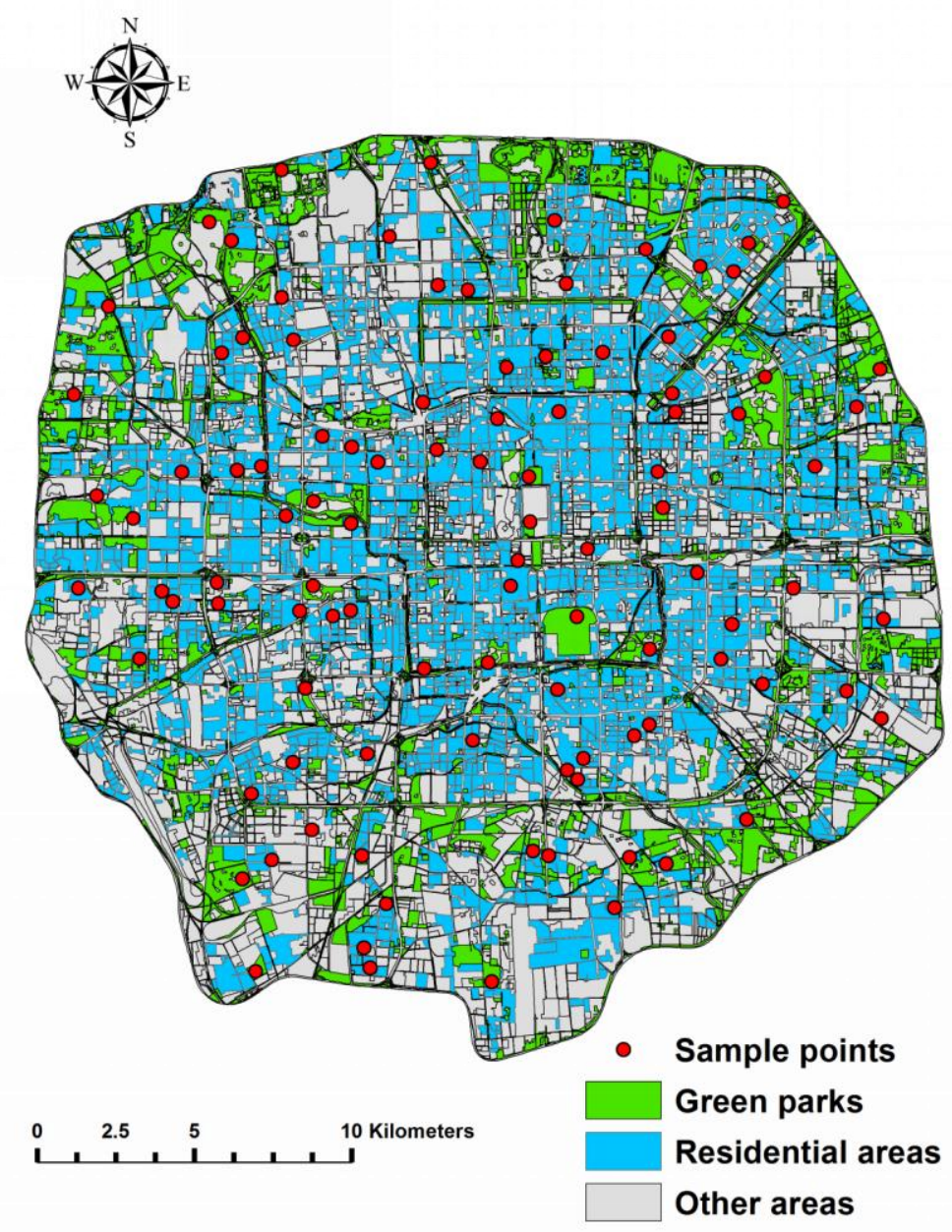

Fig. 4. Study area and soil sampling sites, after Liu et al., 2016.

For indicators where the higher the value, the greater the soil attenuation capacity, the maximum values are suggested as the reference (e.g. Clay and SOM), while for other indicators (e.g. CEC), the median value is used (Peng et al., 2017; Xie et al., 2018). The weights of $\mathrm{pH}$, Clay, SOM and CEC variables are calculated applying the entropy-weight method proposed by Xie et al., 2018, following 3 steps: firstly, standardize the original data of 
all indexes to eliminate influences of different dimensions; secondly, define the entropy of each index; and thirdly, calculate the divergence degree of the intrinsic information of each index.

Table 1

Baseline and observed concentrations of heavy metals.

\begin{tabular}{|c|c|c|c|c|c|c|c|c|}
\hline \multirow{2}{*}{ Elements } & \multicolumn{2}{|c|}{ Baseline $\left(\mathrm{mg} \mathrm{kg}^{-1}\right)$} & \multicolumn{2}{|c|}{$\operatorname{Max}\left(\mathrm{mg} \mathrm{kg}^{-1}\right)$} & \multicolumn{2}{|c|}{$\operatorname{Min}\left(\mathrm{mg} \mathrm{kg}^{-1}\right)$} & \multicolumn{2}{|c|}{ Mean \pm S.D. } \\
\hline & $\begin{array}{l}\text { Residential } \\
\text { area }\end{array}$ & $\begin{array}{l}\text { Green } \\
\text { parks }\end{array}$ & $\begin{array}{l}\text { Residential } \\
\text { area }\end{array}$ & $\begin{array}{l}\text { Green } \\
\text { parks }\end{array}$ & $\begin{array}{l}\text { Residential } \\
\text { area }\end{array}$ & $\begin{array}{l}\text { Green } \\
\text { parks }\end{array}$ & $\begin{array}{l}\text { Residential } \\
\text { area }\end{array}$ & $\begin{array}{l}\text { Green } \\
\text { parks }\end{array}$ \\
\hline $\mathrm{Cd}$ & 19 & 36 & 0.486 & 0.370 & 0.074 & 0.077 & $\begin{array}{l}0.131 \pm \\
0.055\end{array}$ & $\begin{array}{l}0.133 \pm \\
0.056\end{array}$ \\
\hline $\mathrm{Cu}$ & 2000 & 18000 & 44.093 & 57.309 & 9.685 & 9.464 & $\begin{array}{l}18.623 \pm \\
6.728\end{array}$ & $\begin{array}{l}21.695 \pm \\
9.927\end{array}$ \\
\hline $\mathrm{Pb}$ & 400 & 800 & 135.371 & 133.494 & 12.638 & 13.744 & $\begin{array}{l}24.059 \pm \\
15.400\end{array}$ & $\begin{array}{l}31.608 \pm \\
22.48\end{array}$ \\
\hline $\mathrm{Zn}$ & 3500 & 5000 & 184.388 & 136.696 & 35.221 & 29.698 & $\begin{array}{l}78.063 \pm \\
28.062\end{array}$ & $\begin{array}{l}78.859 \pm \\
24.006\end{array}$ \\
\hline
\end{tabular}

Table 2

Related values for attenuation indicators.

\begin{tabular}{|c|c|c|c|c|}
\hline \multirow[t]{2}{*}{ Elements } & \multicolumn{2}{|l|}{ Observed value } & \multirow{2}{*}{$\begin{array}{l}\text { Reference } \\
\text { value }\end{array}$} & \multirow[t]{2}{*}{ Weight } \\
\hline & Residential area & Green parks & & \\
\hline $\begin{array}{l}\text { Bulk density } \\
\left(\mathrm{g} \mathrm{cm}^{-3}\right)\end{array}$ & 2.91 & 2.84 & - & - \\
\hline $\mathrm{pH}$ & 8.265 & 8.247 & 7.5 & 0.25 \\
\hline Clay (\%) & 6.232 & 6.616 & 17.669 & 0.32 \\
\hline $\operatorname{SOM}(\%)$ & 1.18 & 1.103 & 5.272 & 0.27 \\
\hline $\begin{array}{l}\text { CEC } \\
\left(\mathrm{cmol} \mathrm{kg}^{-1}\right)\end{array}$ & 18.129 & 17.621 & 17.936 & 0.16 \\
\hline
\end{tabular}

The disturbances to urban soil caused by rapid urbanization and intensive human activities accelerate the process of environmental degradation. Air pollution generated by the combustion of biomass fuels as well as traffic emission and industrial production has become an emerging environmental issue that directly contributes to soil degradation by means of atmospheric precipitation at both regional and global scale (Pan and Wang 2015). Additionally, traffic emission of wear particles of tires and brake pads is proven to be an important soil pollution input source in the built-up area in Beijing, which increase by $373.1 \%$ and $298.4 \%$ 
during 2002 to 2012, respectively (You 2017). In this work, we assume that atmospheric precipitation and tyre and brake pad wear are the two main sources of heavy metal pollution in the study area. $90 \%$ of heavy metals from these two approaches will flow into the soil ecological system within the $5^{\text {th }}$ ring road. We estimated the average annual atmospheric input and average annual traffic input of heavy metals in soil within the $5^{\text {th }}$ ring road in Beijing from atmospheric deposition flux and traffic emission data for heavy metals in the literature (Pan and Wang 2015; You 2017). The residual rate $(K)$ is suggested as 0.95 to discern the average annual accumulation of $\mathrm{Cd}, \mathrm{Cu}, \mathrm{Pb}$ and $\mathrm{Zn}$. Table 3 shows the data collection for the cumulative coefficient.

\section{Table 3}

Related values for cumulative indicators.

\begin{tabular}{|c|c|c|c|c|}
\hline & $\mathrm{Cd}$ & $\mathrm{Cu}$ & $\mathrm{Pb}$ & $\mathrm{Zn}$ \\
\hline Atmospheric deposition flux $\left(\mathrm{mg} \mathrm{m}^{-2} \mathrm{a}^{-1}\right)^{\mathrm{a}}$ & 0.460 & 19.800 & 19.600 & 86.500 \\
\hline \multirow{2}{*}{$\begin{array}{l}\text { Average annual atmospheric input Residential area } \\
\left(\mathrm{t} \mathrm{a}^{-1}\right)\end{array}$} & 0.198 & 8.529 & 8.443 & 37.262 \\
\hline & 0.0045 & 0.193 & 0.191 & 0.842 \\
\hline Traffic emission $\left(\mathrm{t} \mathrm{a}^{-1}\right)^{\mathrm{b}}$ & 0.030 & 7.120 & 0.830 & 19.600 \\
\hline Average annual traffic input $\left(\mathrm{t} \mathrm{a}^{-1}\right)$ & 0.027 & 6.408 & 0.747 & 17.640 \\
\hline Average annual total input $\left(\mathrm{t} \mathrm{a}^{-1}\right)$ & 0.304 & 18.322 & 12.54 & 69.687 \\
\hline K-value & 0.950 & 0.950 & 0.950 & 0.950 \\
\hline Average annual accumulation $\left(\mathrm{t} \mathrm{a}^{-1}\right)$ & 0.289 & 17.405 & 11.913 & 66.202 \\
\hline
\end{tabular}

${ }^{\mathrm{a}}$ Pan and Wang 2015; ${ }^{\mathrm{b}}$ You 2017

The values used for risk indicators are based on the biogeochemical characteristics of $\mathrm{Cd}$, $\mathrm{Pb}, \mathrm{Cu}$ and $\mathrm{Zn}$, as well as the population, social and natural background of Beijing. Through face to face interviews, five professional experts were asked to provide comments on the weightings allocation to two sub-categories and five indicators. Average values from this process are shown in Table 4. The main basis for scoring each indicator is tabulated in the "reason" column. The score of each indicator is in line with Beijing's situation. 
Table 4

Related values for risk indicators.

\begin{tabular}{|c|c|c|c|c|c|}
\hline Sub-categories & Weight & Indicators & Weight & Score & Reason \\
\hline \multirow[t]{2}{*}{$\begin{array}{l}\text { Risk transfer } \\
\left(\omega_{1}\right)\end{array}$} & 0.5 & $\begin{array}{l}\text { Pollution } \\
\text { characteristics } \\
\left(\omega_{11}\right)\end{array}$ & 0.8 & $\begin{array}{l}\mathrm{Cd}: 2 ; \mathrm{Pb}: 3 ; \\
\mathrm{Cu}: 1 ; \mathrm{Zn}: 1\end{array}$ & $\begin{array}{l}\text { The scores of 1,2, } 3 \text { are assigned according to the } \\
\text { overall evaluation of pollution toxicity, diffusion } \\
\text { paths and potential risks. }\end{array}$ \\
\hline & & $\begin{array}{l}\text { Vegetation } \\
\text { coverage ratio } \\
\left(\omega_{12}\right)\end{array}$ & 0.2 & 2 & $\begin{array}{l}\text { The scores of } 1,2,3 \text { are assigned according to the } \\
\text { ranges of vegetation coverage ratio from low to high: } \\
<20 \%, 20 \sim 50 \%,>50 \% \text {. }\end{array}$ \\
\hline \multirow[t]{3}{*}{$\begin{array}{l}\text { Risk receptor } \\
\left(\omega_{2}\right)\end{array}$} & 0.5 & Land use $\left(\omega_{21}\right)$ & 0.4 & 2 & $\begin{array}{l}\text { According to the land use type defined in GB } \\
36600-2018 \text {, score of } 1 \text { represents the second } \\
\text { category while score of } 2 \text { represents the first } \\
\text { category. }\end{array}$ \\
\hline & & $\begin{array}{l}\text { Population } \\
\text { density }\left(\omega_{22}\right)\end{array}$ & 0.4 & 3 & $\begin{array}{l}\text { The scores of 1,2, } 3 \text { are assigned according to the } \\
\text { ranges of population density from low to high: }<5000 \\
\text { persons, } 5000 \sim 10000 \text { persons, }>10000 \text { persons per } \\
\text { square kilometer. }\end{array}$ \\
\hline & & $\begin{array}{l}\text { Diet structure } \\
\left(\omega_{23}\right)\end{array}$ & 0.2 & 1 & $\begin{array}{l}\text { The diverse sources and safe management of drinking } \\
\text { water and food is assigned the score of } 1 \text {, while the } \\
\text { opposite situation is assigned the score of } 2 \text {. }\end{array}$ \\
\hline
\end{tabular}

\subsection{Scenario analysis}

We designed two representative scenarios to predict long-term change of heavy metal concentration in soil following different accumulative rates. The scenarios are briefly described below.

(1) no intervention: A hypothetical scenario that pollution behavior caused by transportation, human activities and industrial production continues without any intervention, which assumes the observed input and output fluxes of heavy metals remaining at the current level. Considering the heterogeneity of soil pollution, given the maximum concentration of $\mathrm{Cd}, \mathrm{Cu}, \mathrm{Pb}$ and $\mathrm{Zn}$ as the safe threshold value and the screening level in GB 36600-2018 as the upper limit, we predicted the time span over which pollution concentration approached SECC.

(2) decreased input: Since the implementation of the Air Pollution Prevention and Control Action Plan in 2013 and Clean Air Action Plan in Beijing from 2013 to 2017, various efforts including adjustment of energy structure, control of dust pollution, promotion of clean 
production and optimization of traffic planning have led to a significant reduction in pollution emissions and air quality improvement. As a result, various pollutants in the atmosphere have reduced by an average of $30 \%$ by the end of 2015 . Therefore, in our "decreased input" scenario, we assume that $\mathrm{Cd}, \mathrm{Cu}, \mathrm{Pb}$, and $\mathrm{Zn}$ are input at a constant rate of $70 \%$ of the current level.

\section{Results and discussion}

Differing from previous evaluations, the SECC indicator system established in our work defines a comprehensive set of elements to straightforwardly link multidimensions of land function, soil properties, risk mechanism, pollution characteristics and socio-economic activities to soil environment quality. Based on the traditional static capacity model, a modified dynamic capacity model expressing the influence of soil attenuation capacity, cumulative processes and risk characteristics on the dynamic variability of SECC was generated and verified using data from the Beijing urban area, for a more refined assessment of soil environment quality. SECC was estimated in the studied area based on two different accumulative scenarios.

\subsection{SECC of heavy metals}

In terms of the methods shown in Section 2, the first step is to calculate the attenuation coefficient, cumulative coefficient and risk coefficient to match different pollutants and soil function. In the ultimate aggregation step, by launching Eq. (1), the SECC as well as the total environment carrying capacity of $\mathrm{Cd}, \mathrm{Cu}, \mathrm{Pb}$ and $\mathrm{Zn}$ in residential areas and green parks within the $5^{\text {th }}$ ring road in Beijing can be evaluated. The parameters involved and final results are listed in Table 5. 
Table 5

Parameters and result for SECC.

\begin{tabular}{|c|c|c|c|c|c|c|c|c|}
\hline \multirow[b]{2}{*}{ Parameters } & \multicolumn{2}{|l|}{$\mathrm{Cd}$} & \multicolumn{2}{|l|}{$\mathrm{Cu}$} & \multicolumn{2}{|l|}{$\mathrm{Pb}$} & \multicolumn{2}{|l|}{$\mathrm{Zn}$} \\
\hline & $\begin{array}{l}\text { Residential } \\
\text { area }\end{array}$ & $\begin{array}{l}\text { Green } \\
\text { parks }\end{array}$ & $\begin{array}{l}\text { Residential } \\
\text { area }\end{array}$ & Green parks & $\begin{array}{l}\text { Residential } \\
\text { area }\end{array}$ & $\begin{array}{l}\text { Green } \\
\text { parks }\end{array}$ & $\begin{array}{l}\text { Residential } \\
\text { area }\end{array}$ & $\begin{array}{l}\text { Green } \\
\text { park }\end{array}$ \\
\hline Static soil capacity (t) & 2946.680 & 821.825 & 309422.037 & 411938.945 & 58708.883 & 411711.922 & 534387.304 & 112758.69 \\
\hline $\begin{array}{l}\text { Attenuation } \\
\text { coefficient }\end{array}$ & 0.478 & 0.477 & 0.478 & 0.477 & 0.478 & 0.477 & 0.478 & 0.477 \\
\hline $\begin{array}{l}\text { Cumulative } \\
\text { coefficient }\end{array}$ & 1 & 1 & 1 & 1 & 1 & 1 & 1 & 1 \\
\hline Risk coefficient & 0.513 & & 0.645 & & 0.426 & & 0.645 & \\
\hline $\operatorname{SECC}(\mathrm{t})$ & 722.933 & 201.238 & 95446.211 & 126825.364 & 11960.825 & 83717.566 & 164840.370 & 34715.491 \\
\hline $\begin{array}{l}\text { Total environment } \\
\text { carrying capacity (t) }\end{array}$ & 924.171 & & 222271.575 & & 95678.391 & & 199555.861 & \\
\hline
\end{tabular}

The results in Table 5 show that significant differences in estimated soil environmental carrying capacity occur between land use types and between different pollutants. The total environment carrying capacity of heavy metals in residential areas is slightly higher than that in green parks, at $273 \mathrm{kt}$ and $245 \mathrm{kt}$, respectively. But, considering the differing total areas of sampled residential areas and green parks, the soil environmental carrying capacity per $\mathrm{km}^{2}$ of green parks is much higher than that of residential areas, whereby respective average values are about $3000 \mathrm{t} \mathrm{km}^{-2}$ and $500 \mathrm{t} \mathrm{km}^{-2}$. This difference in SECC per $\mathrm{km}^{2}$ between green parks and residential areas is mainly driven by differences in static capacity (Table 5), and is enhanced by the adopted evaluation levels, whereby the baseline concentration for green parks is much higher than that for residential areas. In fact, the observed concentrations of heavy metals between residential area and green parks are similar. The attenuation coefficients, cumulative coefficients and risk coefficients are also similar between residential areas and green parks, suggesting similar performance of factors influencing SECC, such as disturbances, exposure paths and affected population.

In terms of the different pollutants examined, the total environment carrying capacity follows the order $\mathrm{Cu}>\mathrm{Zn}>\mathrm{Pb}>\mathrm{Cd}$. This varies between residential and green park areas: The carrying capacity of heavy metals in residential areas is $\mathrm{Zn}>\mathrm{Cu}>\mathrm{Pb}>\mathrm{Cd}$, while in green parks the order is $\mathrm{Cu}>\mathrm{Pb}>\mathrm{Zn}>\mathrm{Cd}$. The divergence between maxim and minim for 
soil environmental carrying capacity is several orders of magnitude. It is logical that the SECC of different pollutants is highly dependent on their physical and chemical properties, toxicity and availability. Cd displays the greatest threat to soil environmental carrying capacity in both residential areas and green parks, with a total SECC of only 924 t. However, as its average annual accumulation $\left(0.289 \mathrm{t} \mathrm{a}^{-1}\right)$ is the lowest amongst all the studied metals, the time taken to exceed its critical point at its present cumulative level is significant (see below).

\subsection{Early warning for heavy metals}

As assumed in the "no intervention" scenario and "decreased input" scenario, the average annual accumulation of $\mathrm{Cd}, \mathrm{Cu}, \mathrm{Pb}$ and $\mathrm{Zn}$ were calculated as shown in Table 6 . $\mathrm{By}$ launching Eq. (6), the time periods to exceed SECC for $\mathrm{Cd}, \mathrm{Cu}, \mathrm{Pb}$ and $\mathrm{Zn}$ can be projected. According to the classification standards of early warning applied in Figure 3 and our results, the soil quality in the studied area belongs to the $1^{\text {st }}$ early warning level under both the "no intervention" and the "decreased input" scenarios, which means that all metals examined need more than 50 years to reach their grade threshold values i.e. to pose potential health risks. It is clear that the soil heavy metal pollution pressure in Beijing is not overloading carrying capacity currently, and soil capacity will not deteriorate significantly over the short- to medium-term under the scenarios assessed. The principles of present soil management should be consistent with recently issued policies, such as the Soil Pollution Prevention and Control Law of the People's Republic of China, focusing on prevention of emerging pollution, with priority given to protection of unpolluted soil, and enhancing the monitoring of hot spots and key sites.

\section{Table 6}

The prediction for SECC of heavy metals.

\begin{tabular}{llllll}
\hline & & $\mathrm{Cd}$ & $\mathrm{Cu}$ & $\mathrm{Pb}$ & $\mathrm{Zn}$ \\
\hline Average annual & No intervention scenario & 0.289 & 17.405 & 11.913 & 66.202 \\
accumulation $\left(\mathrm{t} \mathrm{a}^{-1}\right)$ & Decreased input scenario & 0.202 & 12.184 & 8.339 & 46.342 \\
The predicted & No intervention scenario & $17507 \sim 17676$ & $30059 \sim 30833$ & $7735 \sim 8763$ & $13672 \sim 14123$ \\
period (a) & Decreased input scenario & $25010 \sim 25252$ & $42942 \sim 44048$ & $11050 \sim 12518$ & $19531 \sim 20176$ \\
\hline
\end{tabular}




\subsection{Uncertainty analysis}

All simulations have some degree of uncertainty, either random or systematic, no matter how accurate the assumptions or models used are. Uncertainty analysis is a critical part of understanding evaluation results and improving models. By analyzing the major sources of uncertainty and evaluating the significance of an input on model outputs, the critical drivers of uncertainty in our model can be found to generate a more precise analysis. In this paper, uncertainties can be framed as having four broad causes:

- Indicator uncertainty: the indicators that have significant contribution are considered as model inputs. Unavoidably, limited by evaluators' knowledge, the indicator framework may include irrelevant or exclude relevant indicators.

- Method uncertainty: the method to quantify SECC indicators, including scoring and weighting, is not unique. Each can generate discrepancies or biases on account of the subjectivity that the methods carry.

- Data uncertainty: the data applied in our case study are mostly referring to data sets in the literature without uncertainty information. However, model inputs may vary compared to real world performance due to experimental uncertainty for data and informational uncertainty for scenarios, that limit the applicability of evaluation results to effective decision making.

\section{Conclusions}

Developing a rigorous framework and method for both SECC and early warning is challenging, particularly given the complexity of the soil system, and pollutant biogeochemical processes. In this study, an initial but meaningful exploration to develop a novel conceptual framework for SECC and early warning has been made and applied to soils in the Beijing urban area, which are transferable and modifiable for use in other international urban settings. This simple, cost-effective, and quantitative tool has promising application in supporting safe and sustainable soil management measures according to the results of SECC evaluation and prediction of soil pollution trends under differing scenarios.

However, aim at supporting optimal decisions on soil management policies, more work 
needs to be done in future research to improve the accuracy of the SECC method and early warning system. In terms of policy implications for future soil management: (1) to clarify SECC, improve the evaluation framework and enact technical guidelines. As pointed previously, many aspects could influence SECC, so the selection of influencing factors based on soil load of pollutants, stress on the soil environment system by social economic activities, and soil carrying capacity for potential risks should be representative depending on land use types and the specific context of the studied sites. (2) to establish an information database for SECC. By an in-depth investigation on soil environment quality at national scale and information sharing among multi-sectors, more precise input data can be collected to support more reliable evaluation results. (3) to implement pilot projects for SECC. By launching an evaluation of SECC at different spatial scales (site, local and regional) in both agricultural land and development land, the theoretical evaluation system of SECC will be constantly optimized to get a clearer understanding of pollution levels and their spatial distribution. (4) to implementing classified and graded soil risk management measures. Based on the prediction of soil pollution changing trends and early waning level in empirical implications, policy decisions will be made in priority of protection, prevention, remediation or monitoring.

\section{Acknowledgements}

This work was supported by Chinese Academy for Environmental Planning, Ministry of Ecology and Environment of the People's Republic of China under Key Issues Study Programme on National Ecological Environmental Protection Plan in 2017 [grant number 2017A118] . 


\section{References}

Acosta, J.A., Gabarrón, M., Faz, A., Martínez-Martínez, S., Zornoza, R., Arocena, J.M., 2015. Influence of population density on the concentration and speciation of metals in the soil and street dust from urban areas. Chemosphere, 134, 328-337. https://doi.org/10.1016/j.chemosphere.2015.04.038.

Aldieri, L., Kotsemir, M., Vinci, C.P., 2019. Environmental innovations and productivity: Empirical evidence from Russian regions. Resour. Policy in press. https://doi.org/10.1016/j.resourpol.2019.101444.

Ashraf, S., Farid, M., Giti, F., 2019. Phytoremediation: Environmentally sustainable way for reclamation of heavy metal polluted soils. Ecotoxicol. Environ. Saf. 174, 714-727. https://doi.org/10.1016/j.ecoenv.2019.02.068.

Bao, Z., Haberer, C., Maier, U., Beckingham, B., Amos, R.T., Grathwohl, P., 2015. Modeling long-term uptake and re-volatilization of semi-volatile organic compounds (SVOCs) across the soil-atmosphere interface. Sci. Total Environ. 538, 789-801. https://doi.org/10.1016/j.scitotenv.2015.08.104.

Bright, D.A., Richardson, G.M., Dodd, M., 2006. Do current standards of practice in Canada measure what is relevant to human exposure at contaminated sites? I: A discussion of soil particle size and contaminant partitioning in soil. Human Ecol. Risk Assess. 12, 591-605. https://doi.org/10.1080/10807030600561816.

Brtnický, M., Pecina, V., Hladký, J., Radziemska, M., Koudelková , Z., Klimánek, M., Richtera, L., Adamcová, D., Elbl, J., Galiová, M.V., Baláková, L., Kynický, J., Smolíková, V., Houška, J., Vaverková, M.., 2019. Assessment of phytotoxicity, environmental and health risks of historical urban park soils. Chemosphere, 220, 678-686. https://doi.org/10.1016/j.chemosphere.2018.12.188.

Cachada, A., Ungaro, F., Filippi, N., Guermandi, M., Malucelli, F., Marchi, N., Staffilani, F., Tarocco, P., 2016. Risk assessment of urban soils contamination: The particular case of polycyclic aromatic hydrocarbons. Sci. Total Environ. 551-552, 271-284. https://doi.org/10.1016/j.scitotenv.2016.02.012.

Calzolari, C., Ungaro, F., Filippi, N., Guermandi, M., Malucelli, F., Marchi, N., Staffilani, F., Tarocco, P., 2016. A methodological framework to assess the multiple contributions of soils to ecosystem services delivery at regional scale. Geoderma 261, 190-203. https://doi.org/10.1016/j.geoderma.2015.07.013.

Cao, Z.Y., Zhang, X.R., Yang, X.M., Wang, P., Hou, G.S., Lin, A.J., 2014. Health risk assessment of heavy metals in dust and soil samples from Beijing. J. Beijing Univ. Chem. Technol. (Nat. Sci.), 41(2), 93-88.

Chai, L.L., Cui, X.T., 2019. Pollution Assessments and Prevention Countermeasures of Heavy Metals of Soil in Main Cities of Hebei Province: Taking Shijiazhuang as an Example. Sci. Technol. Eng. 19(3), 261-268.

Chen, L.L., Song, G., Meadows, M.E., Zou, C.H., 2018. Spatio-temporal evolution of the early-warning status of cultivated land and its driving factors: A case study of Heilongjiang Province, China. L. Use Policy 72, 280-292. https://doi.org/10.1016/j.landusepol.2017.12.017.

Chen, M.Q., Lu, Y.F., Ling, L., Wan, Y., Luo, Z.J., Huang, H.S., 2015. Drivers of changes in ecosystem service values in Ganjiang upstream watershed. L. Use Policy 47, 247-252. https://doi.org/10.1016/j.landusepol.2015.04.005.

Chen, S.B., Wang, M., Li, S.S., Zhao, Z.Q., E, W.D., 2018. Overview on current criteria for heavy metals and its hint for the revision of soil environmental quality standards in China. J. Integr. Agric. 17(4), 765-774. https://doi.org/10.1016/S2095-3119(17)61892-6. 
Chen, Y.N., Ma, J.H., Miao C.H., Ruan X.L., 2020. Occurrence and environmental impact of industrial agglomeration on regional soil heavy metalloid accumulation: A case study of the Zhengzhou Economic and Technological Development Zone (ZETZ), China. J. Clean. Prod. 245, 118676. https://doi.org/10.1016/j.jclepro.2019.118676.

Chon, H.T., Lee, J.U., Lee, J.S., 2017. Chapter 15 - Heavy Metals Contamination of Mine Soil, Their Risk Assessment, and Bioremediation. Assess. Restor. Reclam. Min. Influ. Soils 387-417. https://doi.org/10.1016/B978-0-12-809588-1.00015-3.

Csavina, J., Field, J., Taylor, M.P., Gao, S., Landázuri, A., Betterton, E.A., Sáez, A.E., 2012. A review on the importance of metals and metalloids in atmospheric dust and aerosol from mining operations. Sci. Total Environ. 433, 58-73. https://doi.org/10.1016/j.scitotenv.2012.06.013.

de Miguel, E., Iribarren, I., Chacon, E., Ordonez, A., Charlesworth, S., 2007. Risk-based evaluation of the exposure of children to trace elements in playgrounds in Madrid (Spain). Chemosphere 66, 505-513. https://doi.org/10.1016/j.chemosphere.2006.05.065.

Durães, N., Novo, L.A.B., Candeias, C., da Silva, E.F., 2018. Chapter 2 - Distribution, Transport and Fate of Pollutants. Soil Pollut.: From Monit. to Remediat. 29-57. https://doi.org/10.1016/B978-0-12-849873-6.00002-9.

Fan, J.N., Zhang, Y., He, X.M., Guo, L., Shi, M.F., Chen, H., 2019. BP neural network based prediction and evaluation of heavy metal pollution in soil around the enterprises in key areas of Hubei Province. J. Huazhong Agric. Univ. 38(4), 55-62.

Franco-Uria, A., Lopez-Mateo, C., Roca, E., Fernandez-Marcos, M.L., 2009. Source identification of heavy metals in pastureland by multivariate analysis in NW Spain. J. Hazard Mater. 165, 1008-1015. https://doi.org/10.1016/j.jhazmat.2008.10.118.

Gan, Y.D., Huang, X.M., Li S.S., Liu, N., Li, Y.C.C., Freidenreich, A., Wang,W.X., Wang R.Q., Dai, J.L., 2019. Source quantification and potential risk of mercury, cadmium, arsenic, lead, and chromium in farmland soils of Yellow River Delta. J. Clean. Prod. 221, 98-107. https://doi.org/10.1016/j.jclepro.2019.02.157.

Gao, Y.X., Wang, X.H., Li, Z.T., Li, S., Ma, R., Ma, H., 2015. Environmental Risk Assessment of soil and Early Warning System Research for China. Environ. Sci. Technol., 38(6P), 410-414.

Gonze, M.A., Sy, M.M., 2016. Interception of wet deposited atmospheric pollutants by herbaceous vegetation: Data review and modelling. Sci. Total Environ. 565, 49-67. https://doi.org/10.1016/j.scitotenv.2016.04.024.

Gu, Y.G., Gao, Y.P., Lin, Q., 2016. Contamination, bioaccessibility and human health risk of heavy metals in exposed-lawn soils from 28 urban parks in southern China's largest city, Guangzhou. Appl. Geochem. 67, 52-58. https://doi.org/10.1016/j.apgeochem.2016.02.004.

Guan, Q.Y., Zhao, R., Wang, F.F., Pan N.H., Yang, L.Q., Song, N., Xu, C.Q., Lin, J.K., 2019. Prediction of heavy metals in soils of an arid area based on multi-spectral data. J. Environ. Manag. 243, 137-143. https://doi.org/10.1016/j.jenvman.2019.04.109.

Huang, Y., Deng, M.H., Wu, S.F., Japenga, J., Li, T.Q., Yang, X.E., He, Z.L., 2018. A modified receptor model for source apportionment of heavy metal pollution in soil. J. Hazard. Mater. 354, 161-169. https://doi.org/10.1016/j.jhazmat.2018.05.006.

Islam, M.S., Ahmed, M.K.,Habibullah-AL-Mamun, M., Eaton, D.W., 2017. Human and Ecological Risks of Metals in Soils under Different Land Use in an Urban Environment of Bangladesh. Pedosphere, In Press. https://doi.org/10.1016/S1002-0160(17)60395-3. 
Kheir, R.B., Shomar, B., Greve, M.B., Greve, M.H., 2014. On the quantitative relationships between environmental parameters and heavy metals pollution in Mediterranean soils using GIS regression-trees: the case study of Lebanon. J. Geochem. Explor. 147(Part B), 250-259. https://doi.org/10.1016/j.gexplo.2014.05.015.

Kong, X., Liu, T., Yu, Z., Chen, Z., Lei, D., Wang, Z., Zhang, H., Li, Q.H., Zhang, S.S., 2018. Heavy metal bioaccumulation in rice from a high geological background area in Guizhou Province, China. Sustainability 15, 2281. https://doi.org/10.3390/ijerph15102281.

Kumar, V., Thakur, R.K., Kumar, P., 2019. Assessment of heavy metals uptake by cauliflower (Brassica oleracea var. botrytis) grown in integrated industrial effluent irrigated soils: A prediction modeling study. Scientia Horticulturae, 257, 108682. https://doi.org/10.1016/j.scienta.2019.108682.

Legaz, B.V., De Souza, D.M., Teixeir, R.F.M., Antón, A., Putman, B., Sala, S., 2017. Soil quality, properties, and functions in life cycle assessment: an evaluation of models. J. Clean. Prod. 140(Part 2), 502-515. https://doi.org/10.1016/j.jclepro.2016.05.077.

Li, C., 2016. Study on Soil Environmental Capacity and Carrying Capacity. Resour. Conserv. Environ. Prot. 9, 302-304.

Li, J., Yang, Z.Q., Liu, Z.G., Chen, B., Zheng, G.D., Zhong, X.Y., Qin, Y.X., 2011. Discussion on Prediction Method of Changing Trend for Heavy Metal in Soil in Guigang Area. South. L. Resour. 11, 33-35.

Li, K., Fang, L., He, L., 2019. How population and energy price affect China's environmental pollution? Energy Policy 129, 386-396. https://doi.org/10.1016/j.enpol.2019.02.020.

Li, N.C., 2016. Comprehensive Evaluation Based on Soil Environment Carrying Capacity PSR Model: A case Study in Yellow River Delta Efficient Ecological Economic Zone. Sci. Technol. Manag. L. Resour. 2016, 33(5), 117-125.

Li, Q., Gabay, M., Rubin, Y., Fredj, E., Tas, Eran., 2018. Measurement-based investigation of ozone deposition to vegetation under the effects of coastal and photochemical air pollution in the Eastern Mediterranean. Sci. Total Environ. 645, 1579-1597. https://doi.org/10.1016/j.scitotenv.2018.07.037.

Li, X.G., Li, J., Sui, H., He, L., Cao, X.T., Li, Y.H., 2018. Evaluation and determination of soil remediation schemes using a modified AHP model and its application in a contaminated coking plant. J. Hazard Mater. 353, 300-311. https://doi.org/10.1016/j.jhazmat.2018.04.010.

Li, Z.Y., 2019. Safety Application of Organic Manure Partial Substitution Chemical Nitrogen Fertilizer and Soil Environmental Capacity-Taking Lettuce and Rice as Example. Published by Zhejiang University. Hangzhou, China.

Li, Z.Y., Ma, Z.W., van der Kuijp, T.J., Yuan, Z.W., Huang, L., 2014. A review of soil heavy metal pollution from mines in China: pollution and health risk assessment. Sci. Total Environ. 468-469, 843-853. https://doi.org/10.1016/j.scitotenv.2013.08.090.

Liu, R., Wang, M.E., Chen, W.P., Peng, C., 2016. Spatial pattern of heavy metals accumulation risk in urban soils of Beijing and its influencing factors. Environ. Pollut. 210, 174-181. https://doi.org/10.1016/j.envpol.2015.11.044.

Lockwood, C.L., Stewart, D.I., Mortimer, R.J., Mayes, W.M., Jarvis, A.P., Gruiz, K., Burke, I.T., 2015. Leaching of copper and nickel in soil-water systems contaminated by bauxite residue (red mud) from Ajka, Hungary: the importance of soil organic matter. Environ. Sci. Pollut. Res. 22(14), 10800-10810. https://doi.org/10.1007/s11356-015-4282-4. 
Luo, X.S., Bing, H.J., Luo, Z.X., Wang, Y.J., Jin, L., 2019. Impacts of atmospheric particulate matter pollution on environmental biogeochemistry of trace metals in soil-plant system: A review. Environ. Pollut. 255(Part 1), 113-138. https://doi.org/10.1016/j.envpol.2019.113138.

Ma, H.Y., Yang, X.D., Lv, G.H., 2016. Tendency Prediction about Soil Environmental Capacity of Heavy Metals in Jinghe County in Recent 100 Years. Xinjiang Agric. Sci. 53(8), 1521-1532.

Ma, W.L., Sun, D.Z., Shen, W.G., Yang, M., Qi, H., Liu, L.Y., Shen, J.M., Li, Y.F., 2011. Atmospheric concentrations, sources and gas-particle partitioning of PAHs in Beijing after the 29th Olympic Games. Environ. Pollut. 159, 1794-1801. https://doi.org/10.1016/j.envpol.2011.03.025.

Malina, N., Mazlova, E.A., 2017. Temporal and spatial variation of polychlorinated biphenyls (PCBs) contamination in environmental compartments of highly polluted area in Central Russia. Chemosphere, 185, 227-236. https://doi.org/10.1016/j.chemosphere.2017.06.137.

Martz, M., Heil, J., Marschner, B., Stumpe, B., 2019. Effects of soil organic carbon (SOC) content and accessibility in subsoils on the sorption processes of the model pollutants nonylphenol (4-n-NP) and perfluorooctanoic acid (PFOA). Sci. Total Environ. 672, 162-173. https://doi.org/10.1016/j.scitotenv.2019.03.369.

Morgado, R.G., Loureiro, S, González-Alcaraz, M.N., 2018. Chapter 3-Changes in Soil Ecosystem Structure and Functions Due to Soil Contamination. Soil Pollut.: From Monit. to Remediat. 59-87. https://doi.org/10.1016/B978-0-12-849873-6.00003-0.

Mukherjee, A., Yadav, R., Marmeisse, R., Fraissinet-Tachet, L., Reddy, Sudhakara, M., 2019. Detoxification of toxic heavy metals by serine protease inhibitor isolated from polluted soil. Intern. Biodeterior. Biodegrad. 143, 104718. https://doi.org/10.1016/j.ibiod.2019.104718.

Obade, V.P., 2019. Integrating management information with soil quality dynamics to monitor agricultural $\begin{array}{lllll}\text { productivity. } & \text { Sci. } & \text { Total } & \text { Environ. } & \text { 651(Part 2036-2043. }\end{array}$ https://doi.org/10.1016/j.scitotenv.2018.10.106.

Pan, Y.P., Wang, Y.S., 2015. Atmospheric wet and dry deposition of trace elements at ten sites in Northern China. Atmos. Chem. Phys. Discuss. 15, 951-972.

Peng, C, Ouyang, Z.Y., Wang, M.E., Chen, W.P., Jiao, W.T., 2012. Vegetative cover and PAHs accumulation in soils of urban green space. Environ. Pollut. 161, 36-42. https://doi.org/10.1016/j.envpol.2011.09.027.

Peng, C., Wang, M.E., Chen, W.P., 2016. Modelling cadmium contamination in paddy soils under long-term remediation measures: Model development and stochastic simulations. Environ. Pollut. 216, 146-155. https://doi.org/10.1016/j.envpol.2016.05.038.

Peng, C., Wang, M.E., Chen, W.P., Chang, A.C., Crittenden J.C., 2017. Mass balance-based regression modeling of $\mathrm{Cd}$ and $\mathrm{Zn}$ accumulation in urban soils of Beijing. J. Environ. Sci. 53, 99-106. https://doi.org/10.1016/j.jes.2016.05.012.

Prokop, Z., 2016. Bioavailability and mobility of organic contaminants in soil: new three-step ecotoxicological evaluation. Environ. Sci. Pollut. Res. 23, 4312-4319. https://doi.org/10.1007/s11356-015-5555-7.

Ramón, F., Lull, C., 2019. Legal measures to prevent and manage soil contamination and to increase food safety for consumer health: The case of Spain. Environ. Pollut. 250, 883-891. https://doi.org/10.1016/j.envpol.2019.04.074. 
Razanamahandry, L. C., Andrianisa, H.A., Karoui, H., Podgorski, J., Yacouba, H., 2018. Prediction model for cyanide soil pollution in artisanal gold mining area by using logistic regression. CATENA, 162, 40-50. https://doi.org/10.1016/j.catena.2017.11.018.

Rutgers, M., van Wijnen, H.J., Schouten, A.J., Mulder, C., Kuiten, A.M.P., Brussaard, L., Breure, A.M., 2012. A method to assess ecosystem services developed from soil attributes with stakeholders and data of four arable farms. Sci. Total Environ. 415, 39-48. https://doi.org/10.1016/j.scitotenv.2011.04.041.

Ryzhenko, N.O., Kavetsky, S.V., Kavetsky, V.M., 2017. Cd, Zn, Cu, Pb, Co, Ni phytotoxicity assessment. Pol. J. Soil Sci. 50(2), 197-215.

Shi, T.R., 2019. Prediction and early-warning forecast on heavy metals and their pollution status in agricultural soils in Zhejiang Province, China based on input-output inventory. Published by Northwest A\&F University. Xianyang, China.

Shi, Y.S., Shi, S.Z., Wang, H.F., 2019. Reconsideration of the methodology for estimation of land population carrying capacity in Shanghai metropolis. Sci. Total Environ. 652, 367-381. https://doi.org/10.1016/j.scitotenv.2018.10.210.

Simon, E., Vidic, A., Braun, M., Fábián, I., Tóthmérész, B., 2013. Trace element concentrations in soils along urbanization gradients in the city of Wien, Austria. Environ. Sci. Pollut. Res. 20, 917-924. https://doi.org/10.1007/s11356-012-1019-x.

Song. W., Pijanowski. B.C., 2014. The effects of China's cultivated land balance program on potential land productivity at a national scale. Appl. Geogr. 46, 158-170. https://doi.org/10.1016/j.apgeog.2013.11.009.

Sun, X.L., Wu, Y.J., Zhang, C.S., Wang, H.L., 2019. Performance of median kriging with robust estimators of the variogram in outlier identification and spatial prediction for soil pollution at a field scale. Sci. Total Environ. 666, 902-914. https://doi.org/10.1016/j.scitotenv.2019.02.231.

Tao, M.X., Chen, M., Yang, Q., Hu, L.W., Yang, T., 2017. Assessment in soil heavy metal pollution and safety pre-warning based on GIS. Nonferr. Met. Sci. Eng. 2017, 8(6), 92-97.

Terzaghi, E., Morselli, M., Semplice, M., Cerabolini, B.E.L., Jones, K.C., Freppaz, M., Di Guardo, A., 2017. SoilPlusVeg: an integrated air-plant-litter-soil model to predict organic chemical fate and recycling in forests. Sci. Total Environ. 595, 169-177. https://doi.org/10.1016/j.scitotenv.2017.03.252.

The State Council, 2016. Action plan for soil pollution prevention and control. http://www.gov.cn/zhengce/content/2016-05/31/content_5078377.htm (accessed 24 December 2019).

Thomsen, M., Faber, J.H., Sorensen, P.B., 2012. Soil ecosystem health and services evaluation of ecological indicators susceptible to chemical stressors. Ecol. Indic. 16, 67-75. https://doi.org/10.1016/j.ecolind.2011.05.012.

Turan, İ.D., Dengiz, O., Özkan, B., 2019. Spatial assessment and mapping of soil quality index for desertification in the semi-arid terrestrial ecosystem using MCDM in interval type-2 fuzzy $\begin{array}{lllll}\text { environment. Comput. } & \text { Electron. in } & \text { Agric. } & 164933 .\end{array}$ https://doi.org/10.1016/j.compag.2019.104933.

van Wijnen, H.J., Rutgers, M., Schouten, A.J., Mulder, C., de Zwart, D., Breure, A.M., 2012. How to calculate the spatial distribution of ecosystem services-Natural attenuation as example from The Netherlands. Sci. Total Environ. 415, 49-55. https://doi.org/10.1016/j.scitotenv.2011.05.058.

Wang, B., 2018. Research on prediciton of soil heavy metal pollution and evaluation - early warning of ecological risk. Published by Hebei Agricultural University. Baoding, China. 
Wang, H., He, Y.M., Li, J.W., Liu, S.Y., Li, Y.Z., 2019. Study on indicator system for soil environment carrying capacity based on O-E-R conceptual model. Environ. Prot. Circ. Econ. 39 (4), 39-45.

Wang, M.E., Bai, Y.Y., Chen, W.P., Markert, B., Peng, C., Ouyang, Z.Y., 2012a. A GIS technology based potential eco-risk assessment of metals in urban soils in Beijing, China. Environ. Pollut. 161, 235-242. https://doi.org/10.1016/j.envpol.2011.09.030.

Wang, M.E., Faber, J.H., Chen, W.P., Li, X.M., Markert, B., 2015. Effects of land use intensity on the natural attenuation capacity of urban soils in Beijing, China. Ecotoxicol. Environ. Saf. 117, 89-95. https://doi.org/10.1016/j.ecoenv.2015.03.018.

Wang, M.E., Markert, B., Chen, W.P., Peng, C., Ouyang, Z.Y., 2012b. Identification of heavy metal pollutants using multivariate analysis and effects of land uses on their accumulation. Environ. Monit. Assess. 184(10), 5889-5897. https://doi.org/10.1007/s10661-011-2388-9.

Wangm, R.L., 2005. The Early Warning of Soil Environment of Farmland-A Case of Zhengzhou City Suburb. Published by Chinese Academy of Agricultural Sciences. Beijing, China.

Wei, B., Yang, L., 2010. A review of heavy metal contaminations in urban soils, urban road dusts and agricultural soils from China. Microchem. J. 94, 99-107. https://doi.org/10.1016/j.microc.2009.09.014.

Wuana, R.A., Okieimen F.E., Vesuwe R.N., 2014. Mixed pollutant interactions in soil: implications for bioavailability, risk assessment and remediation. Afr. J. Environ. Sci. Technol. 8(12), 691-706.

Wuana, R.A., Okieimen, F.E., 2011. Heavy metals in contaminated soils: a review of sources, chemistry, risks and best available strategies for remediation. Ecol. 1-20. https://doi.org/10.5402/2011/402647.

Xie, T., 2018. Ecological Effects of Pollution and Purification Function of Residential Green Space Soils in Beijing. Published by University of Chinese Academy of Sciences. Beijing, China.

Xie, T., Wang, M.E., Su, C., Chen, W.P., 2018. Evaluation of the natural attenuation capacity of urban residential soils with ecosystem-service performance index (EPX) and entropy-weight methods. Environ. Pollut. 238, 222-229. https://doi.org/10.1016/j.envpol.2018.03.013.

Yearbook of Beijing Statistical Data (BJ Stats), 2017. Chapter 3-2: permanent residents (1978-2016). Beijing Municipal Bureau of Statistics, Beijing.

You, J., 2017. Estimating the annual heavy metal emission of vehicles and its affection in Beijing. Published by University of Chinese Academy of Sciences. Beijing, China.

Zeng, S.Y., Ma, J., Yang, Y.J., Zhang, S.L., Liu, G.J., Chen, F., 2019. Spatial assessment of farmland soil pollution and its potential human health risks in China. Sci. Total Environ. 687, 642-653. https://doi.org/10.1016/j.scitotenv.2019.05.291.

Zeng, X.L., 2014. Study on the Carry Capacity of Reclaimed Soil Environment in Datun Coal Mining Area. Published by China University of Mining \& Technology. Beijing, China.

Zhang, J., Xu, Y., Wu, Y., Hu, S., Zhang, Y., 2019. Dynamic characteristics of heavy metal accumulation in the farmland soil over Xiaoqinling gold-mining region, Shaanxi, China. Environ. Earth Sci. 78, Article 25. https://doi.org/10.1007/s12665-018-8013-2.

Zhang, Y., Peng, C., Guo, Z.H., Xiao, X.Y., Xiao, R.Y., 2019. Polycyclic aromatic hydrocarbons in urban soils of China: Distribution, influencing factors, health risk and regression prediction. Environ. Pollut. 254(Part A), 112930. https://doi.org/10.1016/j.envpol.2019.07.098.

Zhang, Y., Shen, J., Ding, F., Li, Y., He, Li., 2016. Vulnerability assessment of atmospheric environment

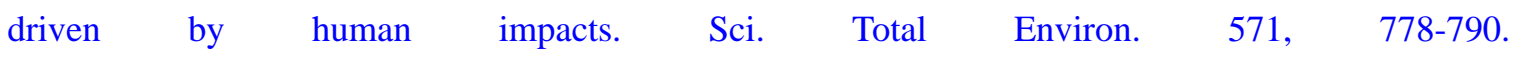
https://doi.org/10.1016/j.scitotenv.2016.07.051. 
Zhang, Y.M., Li, S., Lai, Y.X., Wang, L.Q., Wang, F., Chen, Z., 2019. Predicting future contents of soil heavy metals and related health risks by combining the models of source apportionment, soil metal accumulation and industrial economic theory. Ecotoxicol. Environ. Saf. 171, 211-221. https://doi.org/10.1016/j.ecoenv.2018.12.023.

Zhao, X.Q., Huang, J., Lu, J., Sun, Y., 2019. Study on the influence of soil microbial community on the long-term heavy metal pollution of different land use types and depth layers in mine. Ecotoxicol. Environ. Saf. 170, 218-226. https://doi.org/10.1016/j.ecoenv.2018.11.136.

Zhao, Z.M., Chen, W.P., Jiao, W.T., Wang, M.E., 2012. Modeling the Cd Accumulation in Agricultural Soil Irrigated with Reclaimed Water. Environ. Sci. 33(12), 4115-4120.

Zhou, Q.X., Teng, Y., Liu, Y., 2017. A study on soil-environmental quality criteria and standards of arsenic. Appl. Geochem. 77, 158-166. https://doi.org/10.1016/j.apgeochem.2016.05.001.

Zhou, X.Y., Lei, K., Meng, W., Khu, S.T., Zhao, J., Wang, M.N.,Yang, J.F., 2017. Space-time approach to water environment carrying capacity calculation. J. Clean. Prod. 149, 302-312. https://doi.org/10.1016/j.jclepro.2017.02.110.

Zhou. Q.X., An, J., He, K.X., 2011. Research and prospect on soil-environmental criteria in China. J. Agro Environ. Sci. 30(1), 1-6. 